Article

\title{
"I Drive outside of Peak Time to Avoid Traffic Jams-Public Transport Is Not Attractive Here." Challenging Discourses on Travel to the University Campus in Manila
}

\author{
Robin Hickman ${ }^{1, *(1)}$, Neil Lopez ${ }^{2}$ (i), Mengqiu Cao ${ }^{1}$ (i), Beatriz Mella Lira ${ }^{1}$ \\ and Jose Bienvenido Manuel Biona ${ }^{2}$ \\ 1 Bartlett School of Planning, University College London, London WC1H 0NN, UK; \\ mengqiu.cao.13@ucl.ac.uk (M.C.); beatriz.lira.14@ucl.ac.uk (B.M.L.) \\ 2 Mechanical Engineering Department, De La Salle University, Manila 1004, Philippines; \\ neil.lopez@dlsu.edu.ph (N.L.); jose.bienvenido.biona@dlsu.edu.ph (J.B.M.B.) \\ * Correspondence: r.hickman@ucl.ac.uk
}

Received: 29 January 2018; Accepted: 30 April 2018; Published: 7 May 2018

\begin{abstract}
One of the major narratives in transport policy internationally concerns the promotion of private versus public modes. The Global North has many examples where public transport, walking and cycling networks are well developed, yet examples from the Global South are less evident. There is a historical failure of replicating policies and practices from the Global North, particularly in perpetuating the highway building model, often unsuitable to the cultural contexts in the Global South. This paper examines individual attitudes and discourses concerning travel to De La Salle University campus, in Metro Manila, the Philippines. 42 participants are surveyed using $Q$ methodology. Four discourses are developed, reflecting attitudes to growing automobility in Manila, public transport service provision, the difficulties of travelling in the city and the aspiration for increased comfort whilst travelling. Manila provides an example of the complexities in moving towards greater sustainable travel in the southeast Asian context where levels of private car usage are already high. It is hoped that a greater awareness of the problems of the current travel experiences might lead to us to seek different narratives, where transport systems can be developed which better serve social equity and environmental goals.
\end{abstract}

Keywords: transport; social equity; environment; discourse

\section{Introduction}

Using public transport in many cities in the Global South is a challenge at best, and sometimes an ordeal, and to walk or cycle, or play in the streets is often impossible. There has been a significant change in our transport systems and travel behaviours over the last 50 years. For example, in many cities in southeast Asia, a focus on facilitating vehicle movement and urban highway building has created high levels of private car usage and congestion. Communities have been severed, weak urban planning regimes have not been effective in shaping cities around public transport networks, sprawling metropolitan areas have developed, with enclaves of wealthy neighbourhoods surrounded by shopping malls, lower income neighbourhoods and informal settlements. Alongside, the travel experience and participation in activities and life varies significantly by population cohort, in particular by income group [1]. Traffic congestion means that one-way commutes by private car can approach one or even two hours in length, traffic casualties are high and pedestrian conditions intolerable. Travel by public transport is usually for the lower income groups and the quality of service provision is very poor. This is despite years of so-called development funding, of offering the Global South the 'insights' of transport planning experience and procedures from the Global 
North. Surely more progress could have been made-and we should be seeing more extensive and higher quality public transport networks, helping more people to access residential neighbourhoods, employment opportunities and wider activities, on an equal basis across the city? The Global South provides the context that will make or break our response to the great challenges of social equity and climate change. Yet, in the face of great urban growth projections, it is difficult to be confident that great cities will be planned and developed in the next 20-50 years.

As Vasconcellos advises:

"People in vehicles travel freely. Curb-sides are permanently filled with parked cars and the children and elderly stay inside their homes. Road space has been delivered to other occupants and the city belongs to no one. While the environment is being destroyed and physical violence has become a major cause of urban fatalities, the economic elite is working to benefit from the globalization process and the middle class is struggling to join the venture" [2] (p. 3).

The lower income groups, of course, do not even get a look in-often travelling long distances to poorly paid, insecure jobs and living in overcrowded and insanitary conditions. The use of simplistic market principles in transport provision, using private funding to build and operate infrastructure has led to low quality in delivery, a bias towards urban highway investment-and very limited public transport networks. There needs to be much greater focus in developing transport strategies which meet local needs, consistent and integrated with the objectives of city planning and serving the needs of different cohorts within the population.

A first step is to understand the different views and debate evident in transport, relative to the current travel situation and the likely policy measures and projects being considered. This paper uses qualitative analysis and a case study from Metro Manila, the Philippines, in southeast Asia. Individual attitudes associated with journeys to the university campus at De la Salle University (DLSU) are examined and discourses developed using $\mathrm{Q}$ methodology. The contribution of the paper is in applying Q methodology to help understand the subjectivities associated with travel to the DLSU campus in Manila. The aim is to uncover and examine the problems, opportunities and possibilities concerning travel and the coalitions of views evident relative to the debate on transport, with particular reference to journeys to university campus. Ultimately, we seek to develop a very different discourse in transport and city planning-where transport systems can be developed which support social, environmental and urban planning policy goals.

The analysis is placed within the context of development, including the application of the North American transport and urban planning model over the last century. This can be viewed as a 'regime of governance' [3] and has contributed to many social and environmental problems in the metropolitan area. Although the Philippines gained national independence in 1946, a continuing narrative has been the dominance of investment in urban highways, facilitation of high levels of private car ownership, low priority and resources given to urban planning and a dispersal of development over the extensive metropolitan area. There have been very limited investments in public transport, walking and cycling networks and the public realm-and traffic congestion has grown to be one of the worst of all cities in Asia. Escobar [4] explains, from the South American context, how these concepts of 'development' have been as pervasive and adversely impactful, as their colonial forerunners. Perhaps similar problems can be seen in Manila. The paper is structured as follows: first, the method of analysis is discussed, using $\mathrm{Q}$ methodology; second discourses on travel are developed and interpreted; finally, comments and conclusions are given.

\section{Methods}

\subsection{The Discursive Approach}

There are different approaches to discourse analysis and in this case $Q$ methodology is employed. Originally developed by psychologist William Stephenson $[5,6]$, this can be viewed as a qualitative 
approach to surveying attitudes, with quantitative elements using factor analysis to develop the discourses [7]. Principal component analysis (PCA) is the type of factor analysis used to substantiate and uncover the dominant discourses within the set of attitudinal statements. The name $\mathrm{Q}$ comes from the form of factor analysis that is used. The more conventional $\mathrm{R}$ methodology involves finding relationships between variables (such as gender and age) across the sample of respondents; whereas $Q$ methodology examines relationships between responses to the attitudinal statements. The process involves the following steps:

- Identification of the concourse under debate-in this case, the issues associated with travel to the university campus at DLSU, Manila

- Generation and selection of statements-the Q sample

- Administration of the $Q$ sample to participants through interviews

- Statistical analysis of collected data to extract 'typical' Q sorts through factor analysis (PCA), using Q software (PQMethod 2.35)

- Discursive interpretation of typical Q sorts

Q methodology has only been used a little in transport studies previously, such as [8-13] but with much more intensive usage in energy and environmental studies and wider in politics and psychology. The approach is similar to attitudinal surveys, involving a survey-based statement-ranking but differs in seeking to uncover 'coalitions of belief' within the participants [14]. Hence the focus is not on determining explanatory variables for the responses; instead the value of $\mathrm{Q}$ is in understanding the range of views on a topic, including on the likely effectiveness of policy responses. Care must be taken in interpreting the results, due to the non-random selection of participants and the small sample size. The elaborate, in-depth process of surveying in $Q$ methodology limits the number of participants to a small sample. The number of participants is low, around 30-50 and should be less than the number of statements, which are usually around 40-80. Participants are carefully selected, rather than randomized, to ensure a range of viewpoints [15-17]. The results, therefore, should be viewed only as representative of the available discourses and are not seen as generalizable to the wider population [18]. The value of $\mathrm{Q}$ studies is in understanding the complexity of debate on a topic, in this case travel behaviours, the different viewpoints amongst the population and in particular challenging the mainstream viewpoints that are put forward in society. Hence $Q$ studies can be followed by more extensive survey approaches, examining in more detail some of the issues that are introduced.

\subsection{Generation of the $Q$ Sample}

A number of statements (the $Q$ sample) were developed to represent the varied debate on travel to and from the DLSU campus. An effective Q study depends on meticulous and thoughtful sampling of the propositions, these being reflective of the things people write, say and understand on a particular topic $[19,20]$. 75 statements were developed, starting with an initial longer list of over 120 statements, based on discussion with two transport specialists who live and work in Manila-an academic at DLSU and a transport specialist from the Asian Development Bank. The statements also reflect common transport-related sentiments found in daily conversations with peers in Manila and on social media and in news articles. A concourse was used to help prioritise the statements and provide balance across the issues, using attitudes to the different modes available (pro-car, anti-car, pro-public transport, anti-public transport, pro-active transport and anti-active transport attitudes) and also emerging policy measures.

\subsection{Administering the $Q$ Sort}

All surveys were carried out at the DLSU campus in Manila. The university historically caters to students from middle to high-income groups, though, in recent years, it has provided scholarship grants to a significant portion of its student population, providing opportunities to lower-income cohorts as well. The Philippines is located in southeast Asia and Manila is the capital city of the Philippines, situated on the main island, Luzon, along the narrow strip of land linking the northern 
and southern regions of the island. The city is part of a larger metropolitan area-Metro Manila. The city is the centre of trade, economic activity and higher education in the country, attracting a day time total population of 10.4 million, with a night time population of 9.9 million [21]. The primary modes of public transport in Metro Manila are the three light rail transit lines (LRT), rail, city buses, jeepneys (a local version of minibuses) and utility vans. Private modes include private cars, taxis and ride sharing (i.e., Uber and Grab), tricycles and pedicabs.

Students and staff at DLSU were invited to take part in the survey via internal email. The participants were chosen on an approximate quota basis, with first replies selected up to a broad quota limit by gender and age group. Respondents were selected to give a broad representativeness of the DLSU student population by gender and age group, though there is not an exact match and representativeness of a wider population is not claimed in the analysis. The respondent profile (the $P$ set) is given in Table 1. 42 in-depth interviews were undertaken $(N=42)$. Comparison is also given to the wider Metro Manila population. There is bias in the respondents in terms of age distribution, household car ownership, household income and mode used to travel to school/work. The participants are drawn from well-educated, relatively high-income students and staff and are a private-car dominant group but with a significant portion also using the bus, train and utility van services. A significant group also use jeepney services, however, this is hidden in the aggregated data since this is usually combined with other modes and only the major mode (longest time/distance share in the travel) is shown below. Again, it should be noted that the intention with $Q$ methodology is not to use a representative participant sample but instead to identify a typology within the statement concourse-it is here that the representativeness is attempted, to reflect the range of the debate concerning travel to the university campus.

Table 1. Participant Profile (P set).

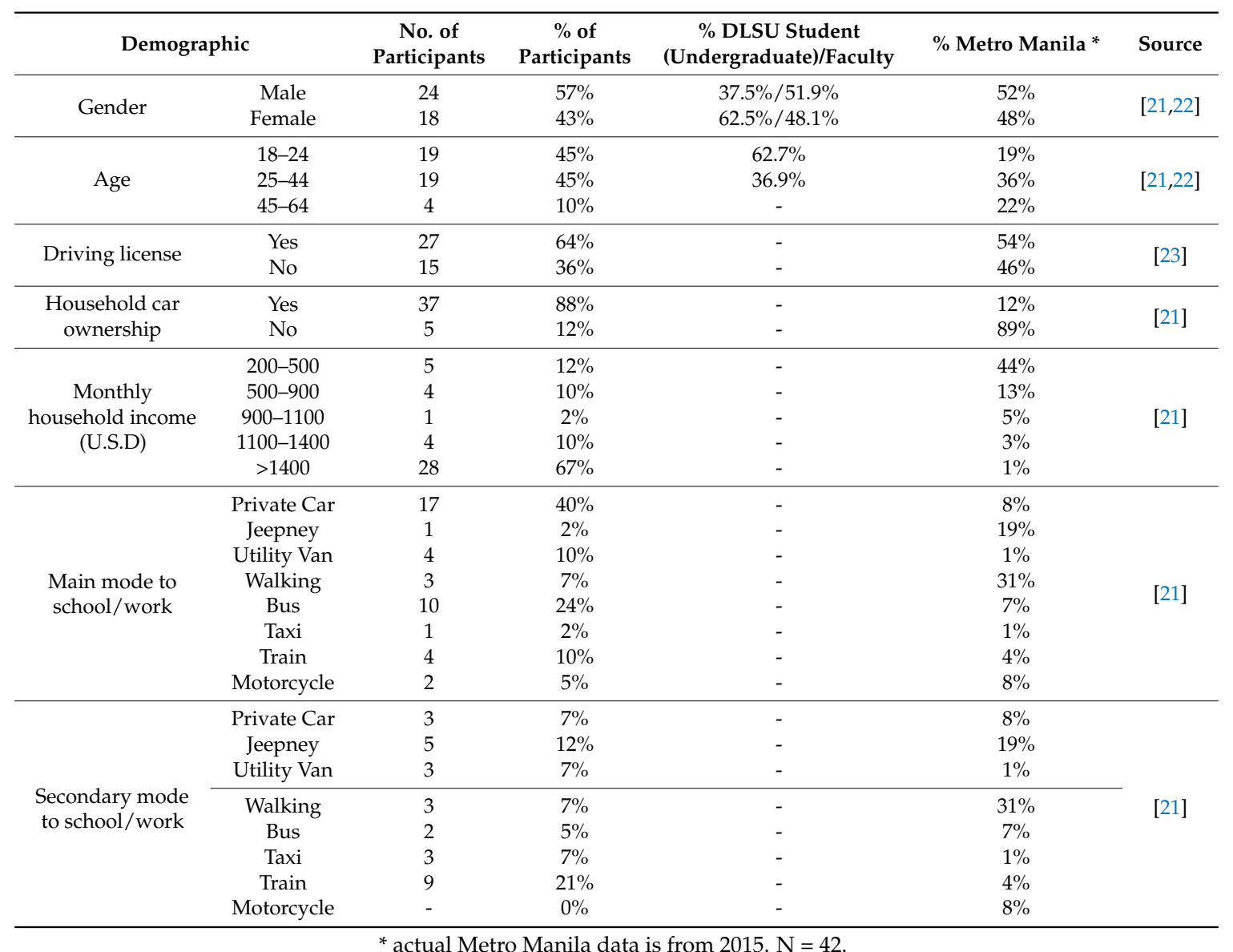

* actual Metro Manila data is from 2015. N = 42. 


\subsection{Administration of the Survey to Participants}

Each participant was invited for an in-depth 45-60 min interview, which involved prioritising and discuss the 75 attitudinal statements, according to their level of agreement, disagreement, or neutrality with them, followed by discussion concerning their responses. A Likert scale, from -4 to +4 , was used to represent disagreement $(-4$ to -1$)$, neutrality $(0)$ and agreement $(+1$ to +4$)$. The number of statements which could be assigned to each particular rating was limited to follow a quasi-normal distribution, with most in the neutral region ( 0 ) and the least in the extremes -4 and +4 ). This 'forced' ranking encourages the participants to give careful consideration to the prioritisation to each statement [14]. This procedure generates some introspection and creates awareness of priorities that didn't exist before the study [13]. The number of statements allowed per category is shown in Table 2.

Table 2. Number of allowable statements per rank.

\begin{tabular}{cccccccccc}
\hline & Agree with Least & \multicolumn{3}{c}{ Agree with Most } \\
\hline Value & -4 & -3 & -2 & -1 & 0 & 1 & 2 & 3 & 4 \\
Number of Statements & 4 & 7 & 9 & 11 & 13 & 11 & 9 & 7 & 4 \\
\hline \multicolumn{1}{c}{$(n=75)$} \\
\hline
\end{tabular}

\section{Factor Analysis}

The statistical processing of the survey data was performed using open-source software called PQMethod (PQMethod was developed by John Atkinson and Steven Brown and adapted by Peter Schmolck. The software and related resources can be accessed from: http://schmolck.userweb.mwn. de/qmethod/). The process includes the following steps:

1. Entering of statement list (Q sample)

2. Entering of scoring of statements per participant (Q sorts)

3. Error proofing, including checking for encoding mistakes, such as double entry of statements

4. Factor analysis, using PCA, for generating factor loadings on unrotated factors

5. VARIMAX factor rotation to improve quality of factor loadings

6. Selection of significantly loading sorts through factor flagging

7. Analysis of rotated factors, where the dominant statements with their corresponding rankings are identified for each discourse (also referred to as 'factors'), including the consensus and disagreement statements

The process follows previous similar studies, such as $[10,13,14]$ and the method is detailed in Brown [15]. The number of significant factors is decided during PCA using eigenvalues and cumulative percentages of the factors (Table 3). A factor is a specific ranking distribution of the statements, which is shared by a significant number of participants. If the loading of a particular participant is significant on a specific factor, it means that specific factor statistically represents his/her own response well. The first consideration to decide the number of factors is to consider eigenvalues $>1$ and to consider when the difference in magnitude between subsequent eigenvalues starts to become relatively small. Second, it is desired that the selected factors are able to explain at least half of the variance, hence the cumulative percentage $>50$ per cent. The incremental variance explained by an additional factor significantly drops beyond 5 factors in the data, hence 4 and 5 factors were explored further with VARIMAX rotation.

After VARIMAX rotation, participants with significant factor loadings are identified through flagging. These are the participants who make up each discourse. The minimum significant loading is determined through the standard error of the study, calculated as $\mathrm{SE}=1 / \sqrt{ } \mathrm{N}$, where $\mathrm{N}$ is the number of $Q$ samples $(N=75)$. Participants with a standard error in excess of $2.58 \times \mathrm{SE}$, are said to be statistically significant at the 0.01 level. Also, the number of confounded participants is considered-these are 
participants who significantly load on more than one factor or do not significantly load on any factor. With this in mind, the minimum significant loading requirement was raised from 0.30 to 0.39 . Using 4 factors provided stronger discourses relative to 5 when factor loadings and distinguishing statements were examined. Using 5 factors in particular provided very few distinguishing statements, hence 4 factors are used to develop the discourses. Participant sort loadings are given in Table 4 . Seven respondents do not load well onto any factor, hence are noted as confounded and are not used in the discourses.

Table 3. Principal Component Analysis (PCA) for the first 20 factors.

\begin{tabular}{cccc}
\hline Factor & Eigenvalues & As Percentages & Cumulative Percentages \\
\hline 1 & 8.70 & $20.72 \%$ & $20.72 \%$ \\
2 & 3.16 & $7.52 \%$ & $28.24 \%$ \\
3 & 2.23 & $5.31 \%$ & $33.55 \%$ \\
4 & 1.98 & $4.71 \%$ & $38.25 \%$ \\
5 & 1.79 & $4.26 \%$ & $42.51 \%$ \\
6 & 1.77 & $4.21 \%$ & $46.72 \%$ \\
7 & 1.65 & $3.93 \%$ & $50.65 \%$ \\
8 & 1.51 & $3.60 \%$ & $54.25 \%$ \\
9 & 1.44 & $3.43 \%$ & $57.68 \%$ \\
10 & 1.37 & $3.26 \%$ & $60.94 \%$ \\
11 & 1.30 & $3.10 \%$ & $64.03 \%$ \\
12 & 1.16 & $2.77 \%$ & $66.80 \%$ \\
13 & 1.10 & $2.61 \%$ & $69.41 \%$ \\
14 & 1.01 & $2.40 \%$ & $71.82 \%$ \\
15 & 0.98 & $2.33 \%$ & $74.15 \%$ \\
16 & 0.94 & $2.23 \%$ & $76.38 \%$ \\
17 & 0.90 & $2.14 \%$ & $78.51 \%$ \\
18 & 0.85 & $2.03 \%$ & $80.54 \%$ \\
19 & 0.80 & $1.91 \%$ & $82.45 \%$ \\
20 & 0.78 & $1.86 \%$ & $84.31 \%$ \\
\hline
\end{tabular}

Table 4. Participant loadings on each rotated factor.

\begin{tabular}{|c|c|c|c|c|c|c|c|c|}
\hline \multirow{3}{*}{$\begin{array}{c}\text { Participant ID } \\
\text { P01 }\end{array}$} & \multicolumn{8}{|c|}{ Factor } \\
\hline & \multicolumn{2}{|l|}{1} & \multicolumn{2}{|l|}{2} & \multicolumn{2}{|l|}{3} & \multicolumn{2}{|l|}{4} \\
\hline & 0.00 & & 0.13 & & 0.19 & & 0.54 & $X$ \\
\hline P02 & -0.05 & & 0.11 & & 0.44 & $X$ & 0.21 & \\
\hline P03 & 0.02 & & 0.43 & $X$ & 0.22 & & 0.36 & \\
\hline P04 & 0.16 & & 0.65 & $x$ & 0.12 & & 0.42 & \\
\hline P05 & 0.35 & & 0.50 & $X$ & 0.23 & & 0.23 & \\
\hline P06 & 0.38 & & 0.33 & & 0.33 & & 0.03 & \\
\hline P07 & 0.35 & & 0.09 & & 0.12 & & 0.60 & $X$ \\
\hline P08 & -0.04 & & 0.62 & $x$ & -0.10 & & 0.17 & \\
\hline P09 & 0.09 & & 0.08 & & -0.04 & & 0.58 & $X$ \\
\hline P10 & 0.45 & $x$ & 0.21 & & 0.30 & & 0.07 & \\
\hline P11 & 0.31 & & 0.20 & & 0.43 & $X$ & 0.22 & \\
\hline P12 & 0.58 & $x$ & -0.27 & & 0.03 & & 0.11 & \\
\hline P13 & 0.60 & $x$ & 0.21 & & 0.00 & & 0.13 & \\
\hline P14 & 0.62 & $x$ & 0.05 & & 0.23 & & -0.04 & \\
\hline P15 & 0.40 & $x$ & 0.25 & & -0.24 & & -0.10 & \\
\hline P16 & 0.34 & & 0.47 & $x$ & 0.27 & & 0.01 & \\
\hline P17 & 0.50 & $x$ & 0.05 & & -0.13 & & 0.14 & \\
\hline P18 & 0.06 & & 0.17 & & 0.45 & $X$ & 0.25 & \\
\hline P19 & 0.59 & $x$ & 0.07 & & 0.04 & & 0.12 & \\
\hline P20 & 0.08 & & 0.11 & & 0.39 & $X$ & -0.32 & \\
\hline P21 & 0.20 & & 0.18 & & 0.53 & $X$ & 0.24 & \\
\hline
\end{tabular}


Table 4. Cont.

\begin{tabular}{|c|c|c|c|c|c|c|c|c|}
\hline \multirow{3}{*}{$\begin{array}{c}\text { Participant ID } \\
\text { P22 }\end{array}$} & \multicolumn{8}{|c|}{ Factor } \\
\hline & \multicolumn{2}{|l|}{1} & \multicolumn{2}{|l|}{2} & \multicolumn{2}{|l|}{3} & \multicolumn{2}{|l|}{4} \\
\hline & 0.39 & $x$ & 0.01 & & 0.11 & & 0.18 & \\
\hline P23 & 0.26 & & 0.62 & $x$ & 0.12 & & -0.16 & \\
\hline P24 & 0.18 & & -0.02 & & 0.11 & & 0.56 & $X$ \\
\hline P25 & 0.34 & & 0.40 & & 0.27 & & 0.14 & \\
\hline P26 & -0.01 & & 0.66 & $x$ & 0.01 & & 0.16 & \\
\hline P27 & 0.31 & & 0.07 & & 0.47 & & 0.44 & \\
\hline P28 & 0.08 & & -0.25 & & 0.33 & & 0.12 & \\
\hline P29 & 0.34 & & 0.20 & & 0.29 & & 0.23 & \\
\hline P30 & -0.05 & & 0.72 & $x$ & 0.25 & & 0.04 & \\
\hline P31 & 0.53 & $x$ & 0.03 & & 0.47 & & 0.11 & \\
\hline P32 & -0.03 & & 0.40 & & 0.52 & $X$ & -0.14 & \\
\hline P33 & 0.06 & & 0.34 & & 0.59 & $X$ & -0.20 & \\
\hline P34 & -0.03 & & -0.04 & & 0.66 & $x$ & 0.09 & \\
\hline P35 & 0.36 & & 0.08 & & 0.51 & $x$ & -0.09 & \\
\hline P36 & -0.15 & & 0.34 & $x$ & 0.25 & & -0.12 & \\
\hline P37 & 0.20 & & 0.65 & $x$ & 0.17 & & 0.25 & \\
\hline P38 & 0.41 & $x$ & 0.12 & & 0.25 & & -0.13 & \\
\hline P39 & 0.09 & & 0.35 & & 0.02 & & -0.27 & \\
\hline P40 & 0.33 & & -0.27 & & 0.36 & & 0.24 & \\
\hline P41 & 0.15 & & 0.48 & $x$ & 0.07 & & -0.03 & \\
\hline P42 & 0.30 & & 0.17 & & 0.52 & $x$ & 0.16 & \\
\hline
\end{tabular}

Note: $\mathrm{X}$ indicates the significant loading (flagging) of a sort onto a factor.

\section{Discourses on Travel}

\subsection{Revealed Discourses}

The following set of four distinct factors, or discourses, concerning travel to the DLSU campus, are developed from the responses to the statements:

- Discourse A: The Individualistic Car Driver

- Discourse B: The Public Transport Advocate

- Discourse C: The Frustrated Traveller

- $\quad$ Discourse D: The Comfort-Seeking Traveller

Table 5 shows the factorised ranking for each statement in each discourse. The statements ranked highest and lowest $(+4,+3,-3,-4)$ are the defining features of the factors that emerge from the $\mathrm{Q}$ analysis. The discourses can be taken as the dominant beliefs and opinions shared by the study participants and in the context of this study, are used to understand their travel behaviour. The labels given to the discourses are the authors' interpretation of the key messages being communicated by each discourse, based on the preferred ranking of statements. 
Table 5. Summary of statement rankings by discourse.

\begin{tabular}{|c|c|c|c|c|c|}
\hline \multirow{3}{*}{ No. } & \multirow{3}{*}{ Statement } & \multicolumn{4}{|c|}{ Statement by Discourse } \\
\hline & & A & B & $\mathrm{C}$ & $\mathbf{D}$ \\
\hline & & The Individualistic Car Driver & The Public Transport Advocate & The Frustrated Traveller & The Comfort- Seeking Traveller \\
\hline 1 & I enjoy the freedom and independence of driving a car & 1 & -2 & 2 & 3 \\
\hline 2 & I enjoy driving nice or expensive cars & -2 & -4 & 1 & 0 \\
\hline 3 & $\begin{array}{l}\text { Car ownership is a universal goal and a natural step } \\
\text { in life's progression }\end{array}$ & 1 & -4 & -1 & -3 \\
\hline 4 & I like driving fast and get a kick out of driving & -4 & -4 & 0 & -4 \\
\hline 5 & $\begin{array}{l}\text { Driving is tiring and stressful-time spent driving is } \\
\text { often the worst part of my day }\end{array}$ & -1 & -1 & -3 & 1 \\
\hline 6 & $\begin{array}{l}\text { I prefer to drive a Sports Utility Vehicle (SUV) or } \\
\text { Sedan in case of floods }\end{array}$ & -1 & 0 & 0 & 3 \\
\hline 7 & $\begin{array}{l}\text { We need to invest more in the urban highway } \\
\text { network-there is too much congestion and we need } \\
\text { more space for cars }\end{array}$ & 4 & -3 & 2 & -2 \\
\hline 8 & I feel safer in a car-it is the safest way to get around & 3 & -1 & 2 & 4 \\
\hline 9 & $\begin{array}{l}\text { Being in a car stuck in traffic is better than riding a } \\
\text { bus or jeepney stuck in traffic }\end{array}$ & -3 & -2 & 1 & 4 \\
\hline 10 & If you are successful in life you tend to drive a nice car & 1 & -3 & 0 & -1 \\
\hline 11 & $\begin{array}{l}\text { Residential car parking spaces are much too difficult } \\
\text { to find-more spaces are required }\end{array}$ & 2 & -4 & -2 & 2 \\
\hline 12 & $\begin{array}{l}\text { I like the carrying capacity and utility of an SUV or } \\
\text { Sedan (for luggage and other passengers) }\end{array}$ & 1 & 0 & 1 & 3 \\
\hline 13 & $\begin{array}{l}\text { It is necessary to own a car in a city like } \\
\text { Manila-public transport is too unreliable }\end{array}$ & -2 & 0 & 0 & -1 \\
\hline 14 & $\begin{array}{l}\text { It is hard to be truly independent and flexible without } \\
\text { a car }\end{array}$ & 0 & -2 & -2 & -2 \\
\hline 15 & $\begin{array}{l}\text { I would use a low emission car or electric car if they } \\
\text { became much cheaper }\end{array}$ & 3 & 1 & -1 & 3 \\
\hline 16 & $\begin{array}{l}\text { I would use an automated car if they became } \\
\text { available-they would be useful in Manila }\end{array}$ & 1 & -2 & 2 & 1 \\
\hline 17 & $\begin{array}{l}\text { Car clubs and car rental (Uber or Grab) are an ideal } \\
\text { model of car ownership-they mean I do not need to } \\
\text { buy my own car }\end{array}$ & 1 & -1 & -3 & 2 \\
\hline
\end{tabular}


Table 5. Cont

\begin{tabular}{|c|c|c|c|c|c|}
\hline \multirow{3}{*}{ No. } & \multirow{3}{*}{ Statement } & \multicolumn{4}{|c|}{ Statement by Discourse } \\
\hline & & $\mathbf{A}$ & B & $\mathrm{C}$ & $\mathbf{D}$ \\
\hline & & The Individualistic Car Driver & The Public Transport Advocate & The Frustrated Traveller & The Comfort- Seeking Traveller \\
\hline 18 & $\begin{array}{l}\text { We should spend much more money to provide an } \\
\text { extensive and reliable Light Rapid Transit (LRT) } \\
\text { network }\end{array}$ & 2 & 3 & 3 & 2 \\
\hline 19 & $\begin{array}{l}\text { Bus Rapid Transit (BRT) should be developed-with } \\
\text { segregated bus lanes to give them priority over the car }\end{array}$ & 4 & 3 & 1 & 0 \\
\hline 20 & $\begin{array}{l}\text { There needs to be much improved public transport } \\
\text { links to Ninoy Aquino International Airport }\end{array}$ & 4 & 2 & 4 & 1 \\
\hline 21 & I use public transport only because I do not have a car & -1 & -3 & -4 & 0 \\
\hline 22 & $\begin{array}{l}\text { The LRT, bus and jeepneys are much too crowded to } \\
\text { enjoy travelling on them at the peak times }\end{array}$ & 4 & 3 & 4 & 3 \\
\hline 23 & $\begin{array}{l}\text { The current public transport network is not good } \\
\text { enough to make car ownership unnecessary }\end{array}$ & -1 & 1 & 4 & -2 \\
\hline 24 & $\begin{array}{l}\text { An important part of travelling on public transport is the } \\
\text { capacity to read, write and use my phone throughout } \\
\text { the journey }\end{array}$ & 0 & 0 & -4 & 4 \\
\hline 25 & $\begin{array}{l}\text { I enjoy riding on jeepneys-they are fun and } \\
\text { convenient }\end{array}$ & -3 & -2 & -3 & -4 \\
\hline 26 & $\begin{array}{l}\text { The LRT Line One extension is important to allow } \\
\text { better connections between Manila and other urban } \\
\text { centres (Cavite) }\end{array}$ & 2 & 4 & 3 & 1 \\
\hline 27 & $\begin{array}{l}\text { We should stop spending money on urban highways } \\
\text { and use the funds for improving public transport }\end{array}$ & -3 & 4 & -1 & 2 \\
\hline 28 & $\begin{array}{l}\text { I don't use public transport because the transfers } \\
\text { are inconvenient }\end{array}$ & -2 & -2 & -2 & -3 \\
\hline 29 & $\begin{array}{l}\text { Public transport should be subsidised to improve the } \\
\text { quality-systems shouldn't need to make a profit }\end{array}$ & 3 & 1 & 1 & 4 \\
\hline 30 & $\begin{array}{l}\text { Provincial public transport terminals are needed to } \\
\text { the north and south of the city-with citybus links into } \\
\text { the city }\end{array}$ & 3 & 4 & 3 & -1 \\
\hline 31 & $\begin{array}{l}\text { It is really only the poorest people in society that use } \\
\text { the bus regularly }\end{array}$ & -4 & -3 & -4 & -2 \\
\hline
\end{tabular}


Table 5. Cont

\begin{tabular}{|c|c|c|c|c|c|}
\hline \multirow{3}{*}{ No. } & \multirow{3}{*}{ Statement } & \multicolumn{4}{|c|}{ Statement by Discourse } \\
\hline & & $\mathbf{A}$ & B & $\mathrm{C}$ & $\mathbf{D}$ \\
\hline & & The Individualistic Car Driver & The Public Transport Advocate & The Frustrated Traveller & The Comfort- Seeking Traveller \\
\hline 32 & $\begin{array}{l}\text { We should add more point-to-point buses between } \\
\text { urban centres-even if they are more expensive }\end{array}$ & 0 & 1 & 0 & -1 \\
\hline 33 & $\begin{array}{l}\text { I would cycle more if there were much better cycling } \\
\text { facilities }\end{array}$ & -1 & 0 & 0 & 0 \\
\hline 34 & $\begin{array}{l}\text { Cycling is not possible in Manila-it is too dangerous } \\
\text { and there are no facilities }\end{array}$ & 0 & 1 & -1 & 2 \\
\hline 35 & $\begin{array}{l}\text { We should invest in an extensive, segregated } \\
\text { cycle network }\end{array}$ & 0 & 1 & 1 & -1 \\
\hline 36 & $\begin{array}{l}\text { Using private concessions is a useful way of } \\
\text { providing transport infrastructure-it saves public } \\
\text { money and provides good quality projects }\end{array}$ & -2 & 0 & 1 & -1 \\
\hline 37 & I enjoy cycling regularly as it gives me exercise & -2 & 0 & -2 & -1 \\
\hline 38 & $\begin{array}{l}\text { Streets should be closed to traffic on Sundays or one } \\
\text { day a month-so walking, cycling and social } \\
\text { interaction can take place in and between urban } \\
\text { centres (similar to the Bogotá Ciclovía) }\end{array}$ & -1 & -1 & -4 & -1 \\
\hline 39 & $\begin{array}{l}\text { Cycling to work isn't feasible due to the distance or } \\
\text { the need to arrive at work in professional attire }\end{array}$ & 2 & 1 & -1 & -1 \\
\hline 40 & $\begin{array}{l}\text { A society where the majority of people cycle to work } \\
\text { is ideal }\end{array}$ & -2 & 2 & 0 & 0 \\
\hline 41 & $\begin{array}{l}\text { I enjoy using cycle hire, such as GrabBike and we } \\
\text { should have more of these facilities provided }\end{array}$ & -3 & -1 & -1 & -3 \\
\hline 42 & I use a motorcycle as it is much quicker through traffic & -4 & -2 & -3 & -3 \\
\hline 43 & $\begin{array}{l}\text { Using a motorcycle is too dangerous and it should } \\
\text { be discouraged }\end{array}$ & 0 & -1 & -1 & 2 \\
\hline 44 & $\begin{array}{l}\text { I use the motorcycle over public transport because it } \\
\text { is cheaper }\end{array}$ & -3 & -2 & -3 & -4 \\
\hline 45 & You should be able to walk anywhere you need to go & 0 & 3 & 1 & 1 \\
\hline 46 & Walking is my favourite means of travel & -3 & 0 & -2 & 1 \\
\hline 47 & $\begin{array}{l}\text { I only tend to walk as it is free-I much prefer other } \\
\text { modes of travel }\end{array}$ & -1 & -3 & -2 & 1 \\
\hline
\end{tabular}


Table 5. Cont

\begin{tabular}{|c|c|c|c|c|c|}
\hline \multirow{3}{*}{ No. } & \multirow{3}{*}{ Statement } & \multicolumn{4}{|c|}{ Statement by Discourse } \\
\hline & & $\mathbf{A}$ & B & $\mathrm{C}$ & $\mathbf{D}$ \\
\hline & & The Individualistic Car Driver & The Public Transport Advocate & The Frustrated Traveller & The Comfort- Seeking Traveller \\
\hline 48 & $\begin{array}{l}\text { We need to radically improve footways and the public } \\
\text { realm-so walking is much more pleasant }\end{array}$ & 0 & 2 & 2 & 3 \\
\hline 49 & $\begin{array}{l}\text { I would much prefer if I could walk, cycle and use } \\
\text { public transport all of the time-and never travel by car }\end{array}$ & -4 & 2 & 0 & -1 \\
\hline 50 & I prefer to work at home and do it whenever I can & -3 & 0 & 1 & -4 \\
\hline 51 & $\begin{array}{l}\text { It is important to locate new development around the } \\
\text { public transport network }\end{array}$ & 3 & 2 & 2 & 1 \\
\hline 52 & $\begin{array}{l}\text { New urban centres and developments should only be } \\
\text { built if they are well served by public transport }\end{array}$ & -1 & 2 & 3 & 1 \\
\hline 53 & $\begin{array}{l}\text { It is difficult to use public transport-many of the } \\
\text { stations are not accessible for those with disabilities or } \\
\text { mobility difficulties }\end{array}$ & -2 & 1 & 1 & 0 \\
\hline 54 & $\begin{array}{l}\text { I would use the bus and jeepney-but it is difficult to } \\
\text { find out where services run from and to }\end{array}$ & -1 & -1 & -1 & 2 \\
\hline 55 & $\begin{array}{l}\text { Public transport connections to informal settlements } \\
\text { need to be much improved }\end{array}$ & 3 & -1 & 2 & -3 \\
\hline 56 & $\begin{array}{l}\text { I do not feel confident cycling in heavy or fast-moving } \\
\text { traffic-cyclists are the most vulnerable of all } \\
\text { road users }\end{array}$ & 0 & 1 & 3 & 2 \\
\hline 57 & $\begin{array}{l}\text { It is important to build the Metro Manila Skyway and } \\
\text { other urban highways-they are critical to improve } \\
\text { congestion in Manila }\end{array}$ & 1 & -1 & 3 & -2 \\
\hline 58 & $\begin{array}{l}\text { My preferred mode of transport is influenced by daily } \\
\text { weather conditions }\end{array}$ & -2 & 0 & 4 & 0 \\
\hline 59 & $\begin{array}{l}\text { Roads and streets are a public good and should be } \\
\text { used more democratically-there should be much } \\
\text { more space for pedestrians and cyclists }\end{array}$ & 0 & 2 & 0 & -2 \\
\hline 60 & We should provide cheaper parking spaces in Manila & 1 & -3 & 0 & 1 \\
\hline 61 & $\begin{array}{l}\text { Taxis are important and should be given greater } \\
\text { priority on our roads }\end{array}$ & 0 & -3 & -3 & -3 \\
\hline 62 & Cars are given too much priority on highways & 1 & 1 & -2 & -3 \\
\hline
\end{tabular}


Table 5. Cont

\begin{tabular}{|c|c|c|c|c|c|}
\hline \multirow{3}{*}{ No. } & \multirow{3}{*}{ Statement } & \multicolumn{4}{|c|}{ Statement by Discourse } \\
\hline & & $\mathbf{A}$ & B & $\mathrm{C}$ & $\mathbf{D}$ \\
\hline & & The Individualistic Car Driver & The Public Transport Advocate & The Frustrated Traveller & The Comfort- Seeking Traveller \\
\hline 63 & $\begin{array}{l}\text { The cost of car parking influences my choice of } \\
\text { retail centre }\end{array}$ & -1 & -2 & -2 & -1 \\
\hline 64 & $\begin{array}{l}\text { It is important to expand Ninoy Aquino International } \\
\text { Airport as an international hub and to help generate } \\
\text { employment in the city }\end{array}$ & 2 & -1 & -1 & 1 \\
\hline 65 & $\begin{array}{l}\text { The international airport should be moved beyond } \\
\text { the metropolitan area }\end{array}$ & 0 & 4 & 3 & -2 \\
\hline 66 & $\begin{array}{l}\text { Travelcards are important to creating a more } \\
\text { 'seamless' travel experience-so that one ticket can be } \\
\text { used on the LRT, bus and all public transport }\end{array}$ & 2 & 3 & 1 & 0 \\
\hline 67 & $\begin{array}{l}\text { We need more pedestrianisation in the urban } \\
\text { centres-it is important to reduce traffic in the } \\
\text { retail areas }\end{array}$ & 2 & 3 & -1 & 0 \\
\hline 68 & $\begin{array}{l}\text { The jeepney fleet needs to be modernised with new } \\
\text { comfortable vehicles and formal stops }\end{array}$ & 0 & 0 & 2 & 0 \\
\hline 69 & $\begin{array}{l}\text { Jeepneys are an iconic mode for Manila-they should } \\
\text { have clean fuel but still be allowed to run as they } \\
\text { currently do }\end{array}$ & 2 & -1 & 0 & 2 \\
\hline 70 & $\begin{array}{l}\text { More information is required on jeepney routing and } \\
\text { scheduling-so it is easier to use them }\end{array}$ & 2 & 1 & 0 & 0 \\
\hline 71 & $\begin{array}{l}\text { Jeepneys should be required to stop at formal } \\
\text { stops only }\end{array}$ & 3 & 2 & 2 & 3 \\
\hline 72 & $\begin{array}{l}\text { Cars should be charged to use the highway-and the } \\
\text { funds used to improve public transport }\end{array}$ & -1 & 2 & -1 & 0 \\
\hline 73 & $\begin{array}{l}\text { New forms of taxation, on vehicle licensing, or } \\
\text { businesses or residential property sales, are required } \\
\text { to fund more investment in public transport schemes }\end{array}$ & -2 & 0 & -3 & 0 \\
\hline 74 & $\begin{array}{l}\text { All vehicles over } 15 \text { years old should not be allowed } \\
\text { to use the highway }\end{array}$ & 1 & 0 & -2 & -2 \\
\hline 75 & $\begin{array}{l}\text { The vehicle licensing system should be used to restrict } \\
\text { and reduce the number of vehicles on the highway }\end{array}$ & 1 & 3 & 0 & -2 \\
\hline
\end{tabular}




\subsection{Discourse A: The Individualistic Car Driver}

Discourse A, The Individualistic Car Driver, is formed by 10 participants and is illustrated by Figure 1 and the statements shown in Table 6.

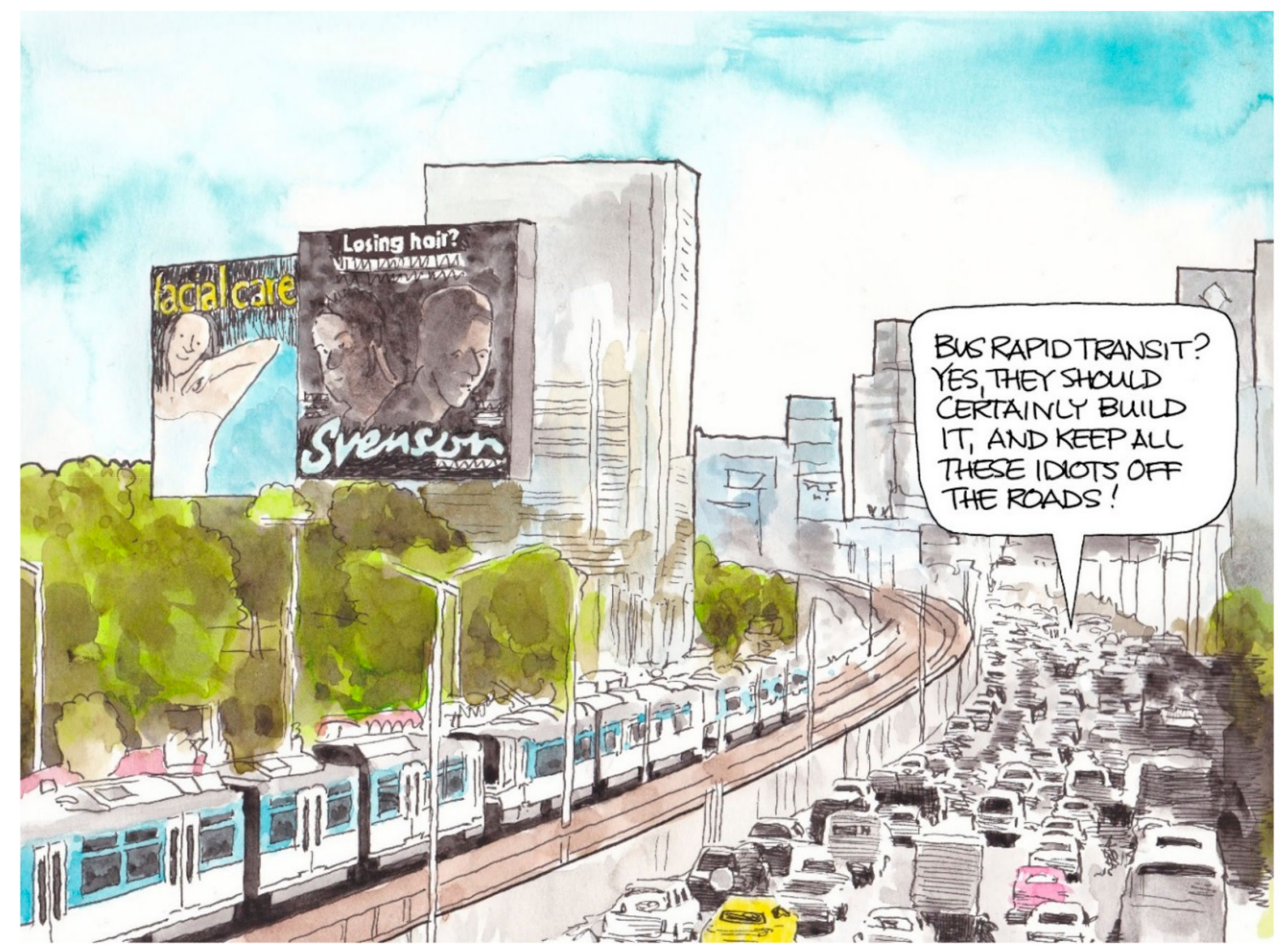

Figure 1. The Individualistic Car Driver.

Table 6. Most agreed and disagreed statements by Discourse A.

\begin{tabular}{cc}
\hline Rank & Statements \\
\hline+4 & $7,19,20,22$ \\
+3 & $8,15,29,30,51,55,71$ \\
-3 & $9,25,27,41,44,46,50$ \\
-4 & $4,31,42,49$ \\
\hline
\end{tabular}

The Individualistic Car Driver is a strong supporter of new infrastructure for highways but also public transport. They believe that we need to invest more in the urban highway network, there is too much congestion and we need more space for cars (7); the LRT, bus and jeepneys are much too crowded to enjoy travelling on (22); jeepneys should be required to stop at formal stops only (71); and they feel safer in a car-it is the safest way to get around (8). But, also, they perceive that BRT should be developed (19); there should be improved public transport links to Ninoy Aquino International Airport (20); and even that public transport should be subsidised to improve the quality-systems shouldn't need to make a profit (29).

There is most disagreement on statements such as I enjoy driving quickly and driving in itself (4); it is only the poorest people in society that use the bus regularly (31); I enjoy riding jeepneys (25); I prefer to walk, cycle and use public transport-and to not travel not by car (49); we should stop spending money on urban highways and using the funds for improving public transport (27). 
The latter two responses suggest that these respondents prefer to drive by car themselves, but they would like others to use public transport and hence support more investment in public transport for other users, presumably so that driving is made easier for themselves by freeing up road space.

Typical participant quotes from this discourse include:

- $\quad$ "There should be more options to make people travel more freely. We should consider people's individual routes" (P10)

- "There are no cycle lanes over here. If we had them, I would cycle but air pollution may still need to be taken into account, as I do not want to inhale polluted air when I am cycling outside with cars" (P22)

- "Cyclists and pedestrians cannot be safe, unless more infrastructure is built [ ... ] cyclists do not have enough space on the road" (P13)

- "I do not like walking at all. Walking takes lots of your time" (P19)

\subsection{Discourse B: The Public Transport Advocate}

Discourse B, The Public Transport Advocate, is formed by 11 participants and is illustrated by Figure 2 and the statements shown in Table 7.

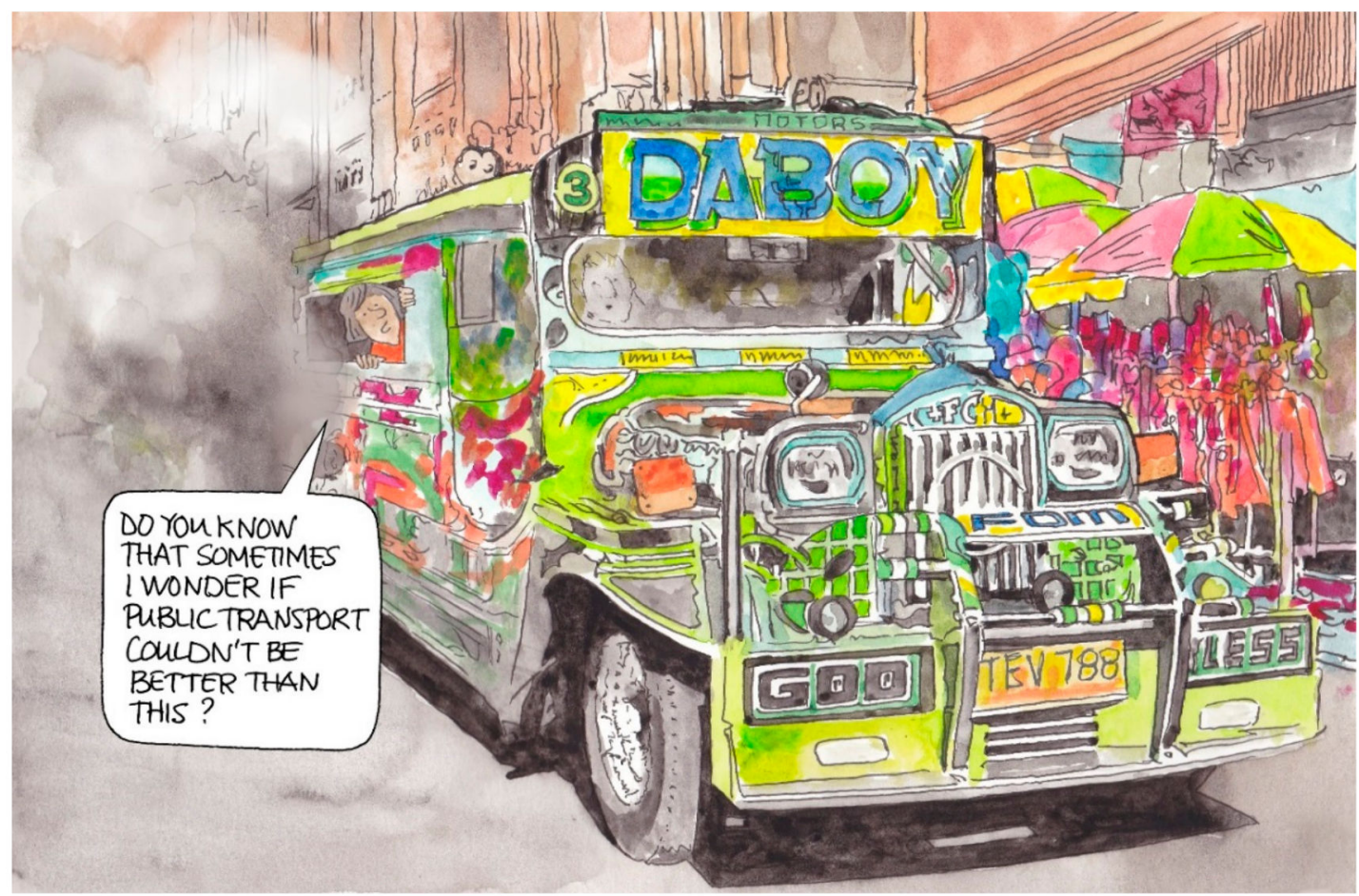

Figure 2. The Public Transport Advocate.

Table 7. Most agreed and disagreed statements by Discourse B.

\begin{tabular}{cc}
\hline Rank & Statements \\
\hline+4 & $26,27,30,65$ \\
+3 & $18,19,22,45,66,67,75$ \\
-3 & $7,10,21,31,47,60,61$ \\
-4 & $2,3,4,11$ \\
\hline
\end{tabular}

The Public Transport Advocate believes that we should stop spending money on urban highways and use the funds for improved public transport (27); much more money can be spent on an extensive 
and reliable LRT network (18); BRT should be developed (19); the LRT, bus and jeepneys are too crowded (22); provincial bus terminals are required (30); we need pedestrianisation in the urban centres (67); and the international airport should be moved beyond the metropolitan area (65).

There is most disagreement on the pro-car status statements, such as I enjoy driving nice or expensive cars (2); car ownership is a universal goal (3); I like driving fast and get a kick out of driving (4); if you are successful in life, you tend to drive a nice car (10). But, also, I use public transport only because I do not have a car (21); we need to invest more in the urban highway network (7); it is only the poorest people in society that use the bus regularly (31); and residential parking spaces are difficult to find-more spaces are required (11).

Typical participant quotes from this discourse include:

- "I have a car, but I still enjoy riding public transport, as I can think about my research when I am riding on public transport. If I drive, I have to focus on my driving" (P23)

- "If people are given access, people will use public transport more" (P26)

- "To encourage shift to public transport, fares should be subsidized. Profit of service providers should not be that high" (P36)

- "Some (private car) drivers choose to use public transport. For example, if they are running late, drivers would just choose to ride public transport" (P41)

- "Public transport should not be privatised and/or should at least be partly state-owned. Both Uber and normal taxis are privatised and compete with each other" (P26)

\subsection{Discourse C: The Frustrated Traveller}

Discourse C, The Frustrated Traveller, expresses a strong dismay with the state of the transport system in Manila. This contrasts with the first two discourses which focus on a preferred strategy or favour particular transport projects. The discourse is formed by 10 participants and is illustrated by Figure 3 and the statements shown in Table 8.

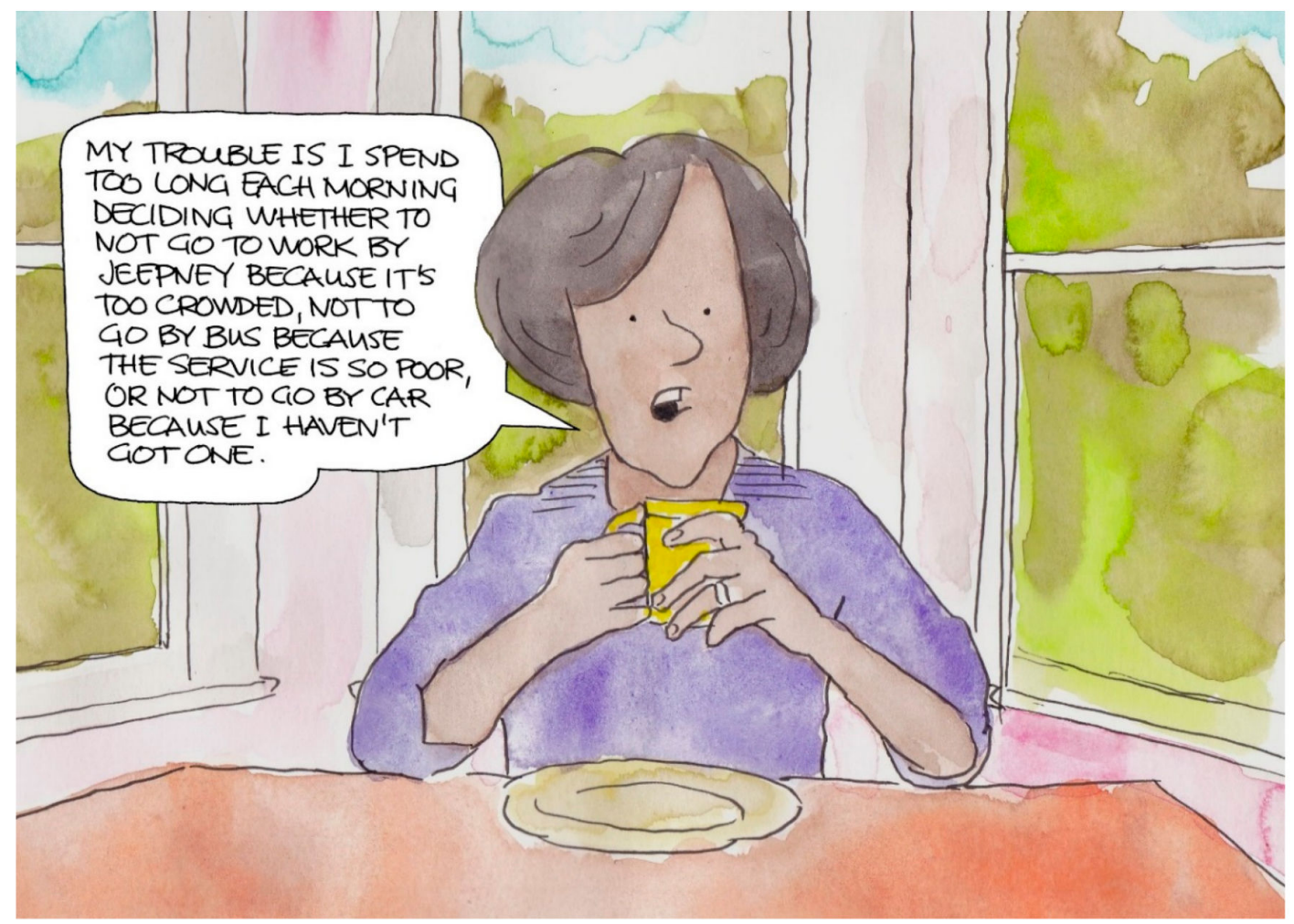

Figure 3. The Frustrated Traveller. 
Table 8. Most agreed and disagreed statements by Discourse C.

\begin{tabular}{cc}
\hline Rank & Statements \\
\hline+4 & $20,22,23,58$ \\
+3 & $18,26,30,52,56,57,65$ \\
-3 & $5,17,25,42,44,61,73$ \\
-4 & $21,24,31,38$ \\
\hline
\end{tabular}

The Frustrated Traveller believes that the LRT, bus and jeepneys are much too crowded to enjoy travelling on them at peak times (22) and the current public transport network is not good enough to make car ownership unnecessary (23). Respondents do not feel confident cycling (56); that we should spend much more money to provide an extensive and reliable LRT network (18); the LRT Line One extension is important and provincial public transport terminals are needed $(26,30)$; and their preferred mode of public transport is influenced by daily weather conditions (58).

There is most disagreement over their use of public transport only because they do not have a car (21); an important part of travelling on public transport is the capacity to read, write and use a phone (24); and enjoyment of riding on jeepneys (25)-again reflecting dissatisfaction with the standard of transport provision. There is also disagreement that it is really only the poorest people in society that use the bus regularly (31); car clubs are an ideal model of car ownership (17); new forms of taxation are required to fund public transport (73); and streets should be closed to traffic on Sundays (38). The response is hence multi-modal but perhaps mostly from the perspective of individual car usage and that this should be much easier to use, again for the respondent themselves.

Typical participant quotes from this discourse include:

- "It is hard to understand the route and information to use a jeepney. You do not know where the route is going. You have to ask the driver, but the driver is always too busy driving and has to deal with receiving fares. He does not really have time to answer questions" [ ... ] "It is too crowded when I use the LRT, buses and jeepneys. I cannot even breathe" (P18)

- "Because of these conditions, I would prefer driving my own car even if it means staying in traffic for hours. I manage traffic by choosing to leave at off-peak hours" [ . . ] "I drive outside of peak time to avoid traffic jams. Public transport is not attractive here. People can leave at different times to avoid the traffic, so it won't be tiring. I quite enjoy driving, especially if there are no traffic jams. It is more comfortable to drive a car home, as public transport is so crowded and it does not always arrive on time" (P21)

- "Taxi drivers are 'silly' drivers, because the government has been lenient in implementing traffic rules. Drivers of public transport vehicles have become unruly" (P32)

\subsection{Discourse D: The Comfort-Seeking Traveller}

Discourse D, The Comfort-Seeking Traveller, is formed by four participants and is illustrated by Figure 4 and the statements shown in Table 9.

Table 9. Most agreed and disagreed statements by Discourse D.

\begin{tabular}{cc}
\hline Rank & Statements \\
\hline+4 & $8,9,24,29$ \\
+3 & $1,6,12,15,22,48,71$ \\
-3 & $3,28,41,42,55,61,62$ \\
-4 & $4,25,44,50$ \\
\hline
\end{tabular}




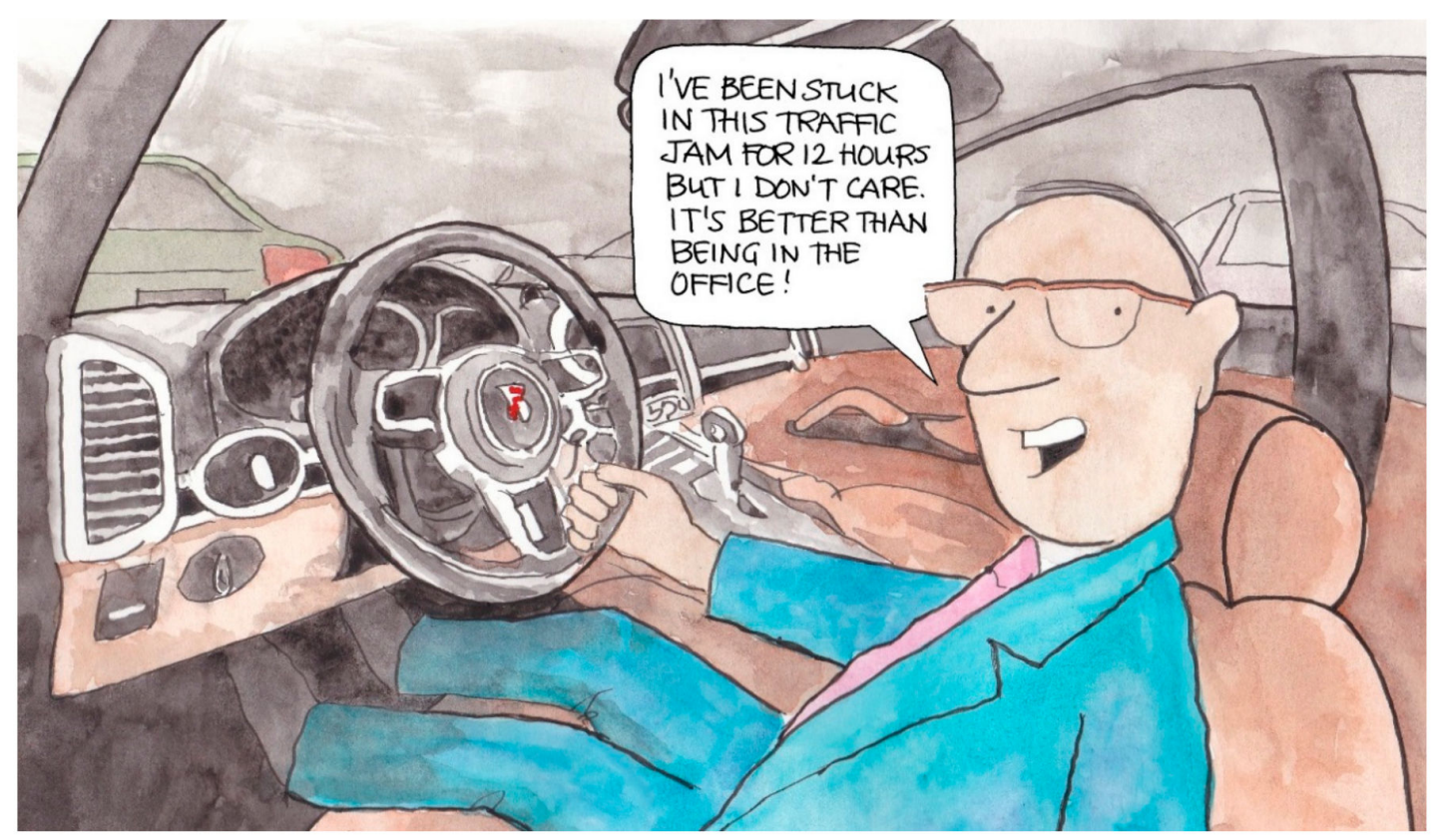

Figure 4. The Comfort-Seeking Traveller.

The Comfort-Seeking Traveller attaches great importance to comfort, convenience and the possibility of productivity whilst travelling. They perceive that it is better to be stuck in traffic in a car rather than in a bus or jeepney (9); an important part of travelling on public transport is the capacity to read, write and use a phone (24); public transport should be subsidised to improve the quality (29); they enjoy the freedom and independence of driving a car (1); prefer to drive an Sports Utility Vehicle (SUV) or Sedan in case of floods (6); like the carrying capacity of a large vehicle for luggage and other passengers (12); and feel safer in a car, believing it to be the safest way to get around (8).

There is most disagreement on enjoying driving in a speedy manner (4); that car ownership is a universal goal and a natural step in life's progression (3). But also, in the use of the non-car modes, such as riding on jeepneys, using GrabBike or motorcycles $(25,41,42,44)$. There is a preference to work at home whenever possible (50) and respondents do not agree that cars are given too much priority on the highways (62).

Typical participant quotes from this discourse include:

- "It is better to be stuck in your own car rather than to be stuck in a jeepney during heavy traffic" (P09)

- "I do not enjoy riding on jeepneys because of the pollution and crowded conditions" (P24)

- "It is very difficult to cycle here, although one of my colleagues often cycles from home to her workplace" (P24)

\section{Comment}

There are no strongly agree $(+4)$ or disagree $(-4)$ statements which cover all respondents and this suggests that different strategies and policy measures will need to be developed for the different viewpoints in society. However, there are certain statements which have moderate agreement $(+1$ to +3 ), neutral ( 0 ) and moderate disagreement $(-3$ to -1 ) by all, representing consensus statements in the sample (Table 10). These reflect the current shortcomings of the public transport system. Everyone agrees that the LRT network has to be extended and made more reliable. They also share the belief that the lack of discipline of jeepney drivers (i.e., stopping even in no loading zones) contribute largely to congestion. A significant number also agree that jeepney routing and scheduling information should be made more available and easier to find, so that the vehicles would be easier to use. With regards to 
negative statements, most disagree that cycling is a desirable option, while many also disagree that transfers make jeepneys inconvenient to use. The cycling issue is particular interesting; there is very little support for investment in cycle infrastructure, with many believing that traffic conditions make cycling impossible in Manila. It may be that cycling infrastructure is inappropriate for Manila, or at least is very difficult to implement at this stage bearing in mind traffic conditions. Hence investment here needs to be very carefully considered and would need to start, at best, with pilot segregated cycle routes to demonstrate that cycling can be a viable mode in Manila, alongside a deliberative exercise illustrating the benefits of cycling for individuals and the city. This may be most appropriate within particular neighbourhoods, such as Makati or Bonifacio, with key links also provided to LRT stations. There is an important point here for strategy development-that the policy measures developed have to be carefully explained to the public, including the reasons for measures that may not be initially accepted. The decision-making process has to be deliberative, with the awareness of the public increased as participation is carried out and strategies developed.

Table 10. Statements with significant consensus.

\begin{tabular}{lc}
\hline \multicolumn{1}{c}{ Statement } & Ranking \\
\hline $\begin{array}{l}\text { We should spend much more money to provide an extensive and } \\
\text { reliable Light Rapid Transit network }\end{array}$ & Moderately Agree \\
Jeepneys should be required to stop at formal stops only & Moderately Agree \\
More information is required on jeepney routing and scheduling-so it is & Moderately Agree to Neutral \\
easier to use them & Neutral to Moderately Disagree \\
I would cycle more if there were much better cycling facilities & Moderately Disagree \\
I enjoy cycling regularly as it gives me exercise & Moderately Disagree \\
I don't use public transport because the transfers are inconvenient & \\
\hline
\end{tabular}

Though car ownership and the share of private car mode trips have decreased in Manila since 1999 [24,25], approximately 65,500 new vehicles are registered every year in Metro Manila alone [23]. A study by Waze [26], across 32 countries, ranked Metro Manila as having the worst traffic conditions and the lengthiest average commute time at $45.5 \mathrm{~min}$. There are LRT infrastructure projects being planned to help move people away from individual vehicle usage [25]. However, these will need to be very extensive, with projects implemented consistently over decades for a wide public transport network to be developed. Kutzbach [27] suggests that growing motorisation in developing countries has a differential feedback mechanism between traffic congestion, buses and private cars. Congestion appears to affect the perceived utility of buses more than private cars, causing more travellers to shift to the private mode, which then causes more congestion. This may be related to the sentiments of Discourse 4, with respondents preferring 'to be stuck in traffic inside a car being better than inside a bus.' Wells and Xenias [28] similarly suggest that the cultural role of the private car has shifted from being a symbol of personal freedom, to instead be used to help with 'cocooning'-appealing to users by offering security and personal space. This is reflected well in the statement, 'I feel safer in a car-it the safest way to get around', which was agreed by many of the respondents. While symbolic and affective motives for car use within the respondents are evident, a larger motivation could be the 'escape' from the undesirable conditions of the public transport system and the flooding events that regularly occur. The public transit system in Metro Manila needs improve its services beyond speed and pricing, to also address journey experience and comfort issues (e.g., modernisation of fleets, improved comfort whilst on the journey and improved journey information). For new users, the public transit system is quite difficult to understand and get used to. The poor reputation of the public transport system drives potential users away from it, before many have even tried.

\section{Conclusions}

Q methodology has helped develop insights on the subjectivities of travel for students and faculty to the DLSU campus, perhaps the first research of this kind in southeast Asia. The analysis identifies 
four significant discourses: The Individualistic Car Driver, the Public Transport Advocate, the Frustrated Traveller and the Comfort-Seeking Traveller. The discourses, as a whole, suggest a radically revised approach to transport planning is required in Manila, moving away from the current heavy dependence on automobility. For almost all people, the focus on highway infrastructure and vehicle movement is not leading to a satisfactory experience of travel, in accessing the university campus and presumably also for wider travel purposes. Certainly, there is a very unequal access and participation in activities, which needs to be changed.

Though we are not claiming representativeness of the results across Metro Manila as a whole, we expect the experience of travel conditions would be similar. This could usefully be tested with further detailed surveys. $Q$ is used to challenge current discourses, not to show representativeness of responses to a wider population. We reflect that the North American model of transport and urban planning has not worked well in Manila, certainly in view of the travel experience to the DLSU campus. The conventional approach to transport (traffic) planning has given too much priority to moving the vehicle around the city and this has severely impacted upon urban design and the public realm. This approach to traffic planning has acted as a default regime of governance over many decades in Manila, presenting a discourse through which the city has been produced. Instead, transport planning can be refocused on the pedestrian and public transport user and on improving the journey experience for all cohorts in society. An alternative narrative can be developed for the emerging transport strategy and project investment, involving much more extensive and higher quality public transport networks, improvements to the public realm and enhanced informal transport provision-but to a detailed specification as yet to be defined. This may mean that a new range of approaches are needed for strategy development, participation, appraisal and evaluation.

The Global North can also learn much from the development of transport planning in Asia. Perhaps a revised transport and city planning model can be developed, with greater levels of participation, deliberation and projects developed suitable to local contexts. Transport planning can include a strengthened normative process, using visioning and scenario exercises to develop agreed strategies, drawing on some of the emerging work on scenario analysis in transport, such as [29-31]. The variety of viewpoints on transport can be better understood using multi-actor assessment, widening the decision-making process beyond the project promoter. The outdated North American model has become hugely ineffective in responding to the great challenges of climate change and social equity and new approaches are required. It is likely that urban planning needs to be more central to the transport planning process, shaping development densities and mixed uses around the public transport network and capturing value uplift for use in infrastructure planning.

In Manila, people drive their own cars to escape the inefficient, unreliable and inadequate public transport networks and to protect themselves from the problems of income inequality and the tropical weather. The viewpoints on the current problems of travel are diverse, with many potential solutions on offer. Transport planners need to understand all of these quite nuanced discourses to ensure that future transport and city planning will be supported and used by the public and to help develop a much more attractive and socially and environmentally sustainable city. The experiences of transport are often heavily embedded in the historical context of a city; whether the current transport systems can be remade depends on new narratives being developed, including new ways of thinking and doing.

Author Contributions: R.H. designed the empirical approach and survey, carried out the surveys and co-wrote and edited the paper; N.L. carried out the surveys, undertook the $Q$ analysis and co-wrote the paper; M.C. and B.M.L. carried out the surveys and commented on the paper; J.B.M.B. commented on the survey statements and the paper.

Acknowledgments: This study is carried out through the Newton Fund Institutional Links project on 'Sustainable Cities and Resilient Transport', with University of Oxford, UCL and DLSU. The authors would like to acknowledge the British Council, the Newton Fund and the Commission on Higher Education, the Philippines, for their support for the project and the students, faculty and staff of De La Salle University, Manila, Philippines and University College London, who helped in the conduct of this study. Thanks to Rob Cowan for the cartoons prepared for the paper.

Conflicts of Interest: The authors declare no conflict of interest. 


\section{References}

1. Hickman, R.; Cao, M.; Lira, B.M.; Fillone, A.; Biona, J.; Lopez, N. Understanding capabilities, functionings and travel in high and low income neighbourhoods in Manila. Soc. Incl. 2017, 5, 161-174. [CrossRef]

2. Vasconcellos, E. Urban Transport, Environment and Equity: The Case for Developing Countries; Earthscan: London, UK, 2001.

3. Böhm, S.; Jones, C.; Land, C.; Paterson, M. Part One, Conceptualizing Automobility: Introduction: Impossibilities of automobility. Sociol. Rev. 2006, 54, 1-16. [CrossRef]

4. Escobar, A. Encountering Development: The Making and Unmaking of the Third World; Princeton University Press: Princeton, NJ, USA, 2012.

5. Stephenson, W. Technique of factor analysis. Nature 1935, 136, 297. [CrossRef]

6. Stephenson, W. The Study of Behavior: Q-Technique and Its Methodology; University of Chicago Press: Chicago, IL, USA, 1953.

7. Stevenson, H. Contemporary discourses of green political economy: A Q method analysis. J. Environ. Policy Plan. 2015, 1-21. [CrossRef]

8. Steg, L.; Vlek, C.; Slotegraaf, G. Instrumental-reasoned and symbolic-affective motives for using a motor car. Transp. Res. Part F 2001, 4, 151-169. [CrossRef]

9. Van Exel, N.; de Graaf, G.; Rietveld, P. Getting from A to B: Operant Approaches to Travel Decision Making. Operant Subj. 2004, 27, 194-216.

10. Rajé, F. Using Q methodology to develop more perceptive insights on transport and social inclusion. Transp. Policy 2007, 14, 467-477. [CrossRef]

11. Van Exel, N.; de Graaf, G.; Rietveld, P. I can do perfectly well without a car! Transportation 2011, 38, $383-407$. [CrossRef]

12. Jones, T.; Pooley, C.G.; Scheldeman, G.; Horton, D.; Tight, M.; Mullen, C.; Jopson, A.; Whiteing, A. Moving around the city: Discourses on walking and cycling in English urban areas. Environ. Plan. A 2012, 44, 1407-1424. [CrossRef]

13. Hickman, R.; Vecia, G. Discourses, travel behaviour and the 'last mile' in London. Built Environ. 2016, 42, 539-553. [CrossRef]

14. Barry, J.; Proops, J. Seeking sustainability discourses with Q methodology. Ecol. Econ. 1999, 28, 337-345. [CrossRef]

15. Brown, S. A primer on Q methodology. Operant Subj. 1993, 16, 91-138.

16. Addams, H. Q methodology. In Social Discourse and Environmental Policy: An Application of Q Methodology; Addams, H., Proops, J., Eds.; Edward Elgar: Cheltenham, UK, 2000.

17. Shabila, N.P.; Al-Tawil, N.G.; Al-Hadithi, T.S.; Sondorp, E. Using Q-methodology to explore people's health seeking behaviour and perception of the quality of primary care services. BMC Public Health 2014, 14, 2. [CrossRef] [PubMed]

18. Steelman, T.A.; Maguire, L.A. Understanding participant perspectives: $Q$ methodology in national forest management. J. Policy Anal. Manag. 1999, 18, 361-388. [CrossRef]

19. Rodgers, R.S. Q methodology. In Rethinking Methods in Psychology; Smith, J.A., Harre, R., van Longenhove, I., Eds.; Sage: London, UK, 1995.

20. Cross, R.M. Exploring attitudes: The case for Q methodology. Health Educ. Res. 2005, 20, 206-213. [CrossRef] [PubMed]

21. Japan International Cooperation Agency (JICA); Department of Transportation and Communications (DOTC). Metro Manila Urban Transportation Integration Study Update and Enhancement Project (MUCEP); Technical Report: Transportation Demand Characteristics; DOTC: Manila, Philippines, 2015.

22. DLSU Diversity Report: Manila, Philippines, 2017. Available online: https://www.collegefactual.com/ colleges/la-salle-university/student-life/diversity/) (accessed on 1 March 2018).

23. Land Transportation Office. Roadmap for Transport Infrastructure Development Registered Motor Vehicles by Classification and Region 2010-2013; LTO: Manila, Philippines, 2014. Available online: http://data. gov.ph/catalogue/dataset/registered-motor-vehicles-by-classification-and-region-2010--2013 (accessed on 1 March 2017). 
24. Japan International Cooperation Agency (JICA); Department of Transportation and Communications (DOTC). Metro Manila Urban Transportation Integration Study (MMUTIS); Technical Report No. 4: Transportation Demand Characteristics; DOTC: Manila, Philippines, 1999.

25. Japan International Cooperation Agency (JICA); National Economic and Development Authority (NEDA). Roadmap for Transport Infrastructure Development for Metro Manila and Its Surrounding Areas; NEDA: Manila, Philippines, 2014.

26. Waze. Global Driver Satisfaction Index. 2015. Available online: https://blog.waze.com/2015/09/globaldriver-satisfaction-index.html (accessed on 1 March 2017).

27. Kutzbach, M. Motorization in developing countries: Causes, consequences and effectiveness of policy options. J. Urban Econ. 2009, 65, 154-166. [CrossRef]

28. Wells, P.; Xenias, D. From 'freedom of the open road' to 'cocooning': Understanding resistance to change in personal private automobility. Environ. Innov. Soc. Trans. 2015, 16, 106-119. [CrossRef]

29. Geurs, K.; Van Wee, B. Backcasting as a Tool for Sustainable Transport Policy Making: The Environmentally Sustainable Transport Study in the Netherlands. Eur. J. Transp. Infrastruct. Res. 2004, 4, 47-69.

30. Åkerman, J.; Höjer, M. How much transport can the climate stand? Sweden on a sustainable path in 2050. Energy Policy 2006, 34, 1944-1957. [CrossRef]

31. Hickman, R.; Banister, D. Transport, Climate Change and the City; Routledge: Abingdon, UK, 2014.

(c) 2018 by the authors. Licensee MDPI, Basel, Switzerland. This article is an open access article distributed under the terms and conditions of the Creative Commons Attribution (CC BY) license (http://creativecommons.org/licenses/by/4.0/). 